\section{La exaltación del deseo en la propaganda militar de Colombia}

Comunicación

número 42

Enero-junio

$2020 \mid$ pp. 51-67

\section{Carlos Mario Berrío Meneses}

Doctor en Comunicación audiovisual, publicidad y relaciones públicas de la Universidad Complutense de Madrid

\section{Desire exaltation in military propaganda of Colombia}

DOI: http://dx.doi.org/10.18566/comunica.n42.a04

Fecha de recepción: 26 de febrero de 2020

Fecha de aceptación: 5 de junio de 2020

\section{Resumen}

El conflicto armado colombiano ha sido ampliamente estudiado desde diversos enfoques y disciplinas, por lo que, en algunos círculos académicos, incluso, se afirma que el fenómeno ha sido sobrediagnosticado. A pesar de esto, es posible advertir una escasez de investigaciones que afronten el discurso propagandístico que han realizado los diversos actores armados con el fin de obtener el apoyo popular a su causa. Por esta razón, esta investigación abordó el discurso propagandístico televisivo realizado por el Estado colombiano en las campañas Los héroes en Colombia sí existen y La desmovilización es la salida, las cuales tenían por objetivo, en primer lugar, mejorar la imagen del Ejército de Colombia ante la opinión pública y ante sus mismos integrantes, y, en segundo lugar, aumentar el número de desertores en los grupos armados que combatían al Estado. El estudio se realizó a través del análisis textual de los spots televisivos transmitidos por los diversos canales de televisión nacional de Colombia entre 2006 y 2012, fundamentado en la teoría del relato de Jesús González Requena (2006). La investigación demostró que, contrario a lo que podría esperarse de la propaganda, las campañas escapan de tópicos morales o ideológicos y convierten el deseo en el elemento primordial sobre el cual se articulan casi la totalidad de los spots. Así, mientras los miembros del Ejército se presentan como objetos de deseo ante el televidente, las organizaciones guerrilleras se presentan como obstáculos para acceder a lo deseado.

\section{Abstract}

The Colombian armed conflict has been widely studied from various approaches and disciplines, so in some academic circles it is claimed that the phenomenon has even been over-diagnosed. In spite of this, it is possible to
Docente investigador de la Facultad de Comunicación de la Universidad de Medellín, Colombia Vinculado a los grupos de investigación Comunicación, Organización y Política (COP) y Holográfico de la misma universidad caberrio@udem.edu.co http: / / orcid.org/0000-00020172-5586

Palabras clave Propaganda, comunicación, deseo, Colombia, Ejército.

\section{Keywords}

Propaganda, communication, desire, Colombia, army. 
notice the few investigations that address the propaganda speech that the various armed actors have carried out in order to obtain popular support for their cause. For this reason, this investigation addressed the television propaganda speech made by the Colombian State in the campaigns Los héroes en Colombia sí existen and La desmovilización es la salida, which were aimed, in the first place, to improve the image of the Colombian Army before the public opinion and before their same members and, secondly, they tried to increase the number of deserters in the armed groups that fought the State. The study was carried out through a textual analysis of the television spots broadcast by the various national television channels of Colombia between 2006 and 2012. The investigation showed that, contrary to what one might expect from propaganda, campaigns escape from moral or ideological topics and make desire the main element on which almost all of the spots are articulated. So, while members of the Army present themselves as objects of desire before the viewer, guerrilla organizations present themselves as obstacles to accessing what is desired.

\section{Introducción}

La intensificación del conflicto armado colombiano a finales de los años noventa obligó a las Fuerzas Militares y, especialmente, al Ejército de Colombia, a emprender una serie de reformas al interior del estamento castrense que culminarían a inicios del siglo XXI. Dicha transformación es llamada "la reforma militar" por Vargas y Patiño (2006), mientras que, en la actual doctrina de esta fuerza, se le conoce como "la modernización del Ejército" (Ejército de Colombia, 2016). Si bien estas innovaciones, en la mayoría de los casos, se concentraron en aspectos netamente militares, como la movilidad aérea y la creación de unidades especializadas, también concedieron una importancia notable al uso de diversas herramientas de comunicación que, claramente, pueden clasificarse en el ámbito de la propaganda militar.

Así, a inicios del siglo XXI los colombianos presenciamos un aumento en el volumen de la información que circulaba en los medios de comunicación masiva en torno al conflicto armado. La constante información noticiosa de victorias militares - producida por el aparato propagandístico del Ejército(Correa, 2006) se combinaba con un flujo de campañas televisivas que invitaban a los colombianos a disfrutar su país y a viajar por él. Incluso, advertían que los extranjeros que llegaban a Colombia decidían quedarse a vivir en el país, sugiriendo que una época de bienestar había llegado. A toda esta información se sumaban las campañas Los héroes en Colombia sí existen y La desmovilización es la salida, las cuales, por una parte, seducían 
a la opinión pública afirmando que los soldados del Ejército eran héroes, y, por otra, invitaban a los miembros de grupos subversivos a desmovilizarse y retomar la vida civil.

Las acciones comunicativas encabezadas por estas dos campañas propagandísticas continúan hoy en día, y son el ejemplo de propaganda militar más importante en la historia reciente del país, pues las campañas posteriores realizadas por el Ministerio de Defensa de Colombia no han logrado superar el impacto de estas, ni en términos de inversión ni de exposición mediática. Además, la campaña Los héroes en Colombia sí existen, desarrollada inicialmente para el Ejército de este país, dio luz a la campaña Héroes multimisión, que se convirtió en una suerte de marca que cobija, actualmente, a todas las Fuerzas Militares de Colombia. De manera similar, estos spots iniciales de la campaña La desmovilización es la salida abrieron paso a una serie de acciones posteriores bastante notorias y a unos spots televisivos que continuaron transmitiéndose en medios de comunicación masiva hasta 2014, cuando se consolidaba el proceso de negociación entre el Estado colombiano y las FARC-EP.

Asimismo, es posible destacar que es relativamente fácil encontrar ejemplos de propaganda militar en el mundo occidental e incluso es sencillo rastrear spots producidos con el fin de incentivar los procesos de reclutamiento en diversas fuerzas armadas del mundo. Sin embargo, es en extremo dificil hallar spots televisivos de propaganda militar que busquen el apoyo directo de la población civil hacia uno de los contendientes de un conflicto armado y busquen disgregar a los miembros del otro. Estas son razones de sobra que ameritan abordar este tema que, hoy en día, mantiene plenamente su relevancia.

Por lo anterior, esta investigación se centró en el estudio de las dos campañas y para ello se fundamentó en la teoría del relato que propone Jesús González Requena (2006) y apeló a la metodología del análisis textual que se expone en El texto: tres registros y una dimensión (González, 1996). Este análisis consiste en un deletreamiento de cada uno de los spots que componen la muestra, el cual implica una mirada atenta y detenida a dos elementos fundamentales de los spots. Por una parte, a su estructura narrativa, y, por otra, a la enunciación fílmica.

Así, en primer lugar, se analiza cómo se ha construido el relato a través de las secuencias narrativas y del análisis de las funciones de los personajes y su relación con el eje de la donación y la carencia. En otras palabras, con las tareas que cumplen y los deseos que persiguen, lo que obliga a examinar sus cualidades y su carácter heroico. En segundo lugar, la enunciación fílmica consiste en las formas visuales que se han utilizado para narrar la obra. Es decir, el uso de planos, escenografías, gamas cromáticas, etc. 

complementarias en otros medios como la radio y la publicidad exterior visual, esta investigación cerró la muestra en aquellos spots que fueron registrados en el Anuario de la Publicidad en Colombia, una publicación en la que la industria publicitaria colombiana registra los mejores anuncios según su criterio. Así, para este artículo, nuestro análisis se centra en cinco spots televisivos de la campaña Los héroes en Colombia si existen y dos de La desmovilización es la salida.

\section{La propaganda y sus usos en el Ejército de Colombia}

Es posible entender la propaganda como “[...] el uso, más o menos deliberado, planeado y sistemático de símbolos, principalmente mediante la sugestión y otras técnicas psicológicas conexas, con el propósito, en primer lugar, de alterar y controlar las opiniones, ideas y valores, y en último término, de modificar la acción manifiesta según ciertas líneas predeterminadas" (Young, 1967, p. 242).

Si bien esta definición es relativamente precisa, no es unánimemente aceptada en las ciencias sociales, pues es posible ver multiplicidad de definiciones debido a que no existe un consenso alrededor de lo que significa la palabra "propaganda". En parte, esto quizá se debe a que el significado de la palabra ha ido transformándose con el tiempo, cambio también impulsado por la aparición de nuevas disciplinas y profesiones que han abordado la persuasión masiva desde diversas aproximaciones.

No obstante, todas las definiciones de propaganda pueden categorizarse de acuerdo con una variable primordial: el alcance de lo que se considera propaganda y los campos en que actúa. Así, es posible configurar dos visiones de la propaganda, una amplia y una reducida. En la primera se considera que esta actúa en campos tan diversos como la economía, donde, por ejemplo, algunos autores enmarcados en esta visión plantean que la publicidad es solo una forma específica de la propaganda. De manera similar, se plantea la existencia de una propaganda moral (Thomson, 1999), a través de la cual una sociedad les enseñaría a sus miembros a reconocer la diferencia entre lo que se considera malo y bueno. Incluso, autores como Faucher (2019) afirman la existencia de una propaganda cultural como una suerte de extensión de las relaciones internacionales.

Por otra parte, las definiciones enmarcadas en la visión restringida consideran la propaganda como una actividad comunicativa que se limita al campo de la política, la religión y la guerra. Incluso, algunos pueden considerarla no más que un conjunto de herramientas persuasivas que se 
aplican al ejercicio de la política y que se enmarcan en el ejercicio de las relaciones públicas, como lo hace Palencia-Lefler (2008).

Lo anterior obliga a que quien esté dispuesto a abordar el tema asuma una clara posición acerca de lo que entiende por propaganda, pues de lo contrario será inevitable caer en imprecisiones. Por tal razón, esta investigación asumió la definición elaborada por Young (1967) que aparece líneas arriba. Y si bien este autor no hace precisión sobre el campo donde actúa la propaganda, esta investigación se ha sustentado en Thomson (1999) y en Pizarroso (2005), quienes afirman que la propaganda utilizada en el contexto de un conflicto bélico -que no obligatoriamente tiene que ser interestatal- es llamada "propaganda militar".

Ahora, si bien diversos autores pueden proporcionar ejemplos de acciones propagandísticas en la Edad Media o incluso en tiempos más lejanos, son las dos guerras mundiales las que han arrojado mayores avances técnicos en esta actividad y se han convertido en casos de estudio bastante interesantes para la comunidad científica. Sin embargo, el importante papel que la propaganda desempeñó en estos conflictos es, precisamente, la razón principal para desarrollar la connotación altamente negativa que hoy tiene. Nótese que hoy la palabra "propaganda" se ha convertido en un término peyorativo y descalificador que numerosas instituciones y personajes públicos evitan utilizar.

Huici (2004) y Pizarroso (2009) coinciden en afirmar que esta es la razón por la cual Occidente, después de la Segunda Guerra Mundial, ha evitado utilizar la palabra "propaganda" para describir este ejercicio de persuasión masivo. Así, se han inventado eufemismos para nombrarla, tales como "comunicación política”, "marketing político", "publicidad política”, etc. En palabras de Pizarroso, "recordemos que lo que los americanos [sic] llaman relaciones públicas en el terreno de la vida política y social no es otra cosa que propaganda entendida en su más amplio sentido y sin las frecuentes connotaciones negativas" (citado en Fernández, 2006, p. 167).

Esta aversión por la palabra ha sido adoptada también por las diversas fuerzas armadas de Estados Unidos y, especialmente, por el ejército de ese país, razón por la cual la palabra en sí no aparece en su doctrina. "De hecho, hoy se habla en Estados Unidos descaradamente de perception management como eufemismo del término propaganda" (Pizarroso, 2005, p.44). De manera similar, el término "operaciones psicológicas" - una forma específica de la propaganda militar enfocada en afectar enemigos y neutrales- también ha sufrido la misma suerte, razón por la cual los militares norteamericanos han buscado otras expresiones con connotaciones más suaves. Así, en los años noventa, el Centro de Armas Combinadas del Ejército de Estados Unidos 
advirtió que la expresión "operaciones psicológicas" (PSYOP, por sus siglas en inglés) se convirtió en un término peyorativo dentro y fuera del ámbito militar, razón por la cual desarrolló la doctrina para las Information Operations, las cuales subsumían la labor de las PSYOP a otras especialidades que buscan impactar al bando adversario en un conflicto armado (Boyd, 2007).

Los militares colombianos no han sido ajenos a esta situación, por lo que también han evitado usar el término en sus actividades de este tipo. Así, las unidades encargadas de dichas actividades eran conocidas como "departamentos de relaciones civiles y militares" y, valga la pena mencionarlo, actuaban de manera poco coordinada y muchas veces dirigidas por oficiales y suboficiales que no tenían formación en el campo específico. Por ello, a inicios de los años noventa, el Ejército creó un centro de formación en el tema, en el cual se empezaron a brindar los primeros cursos de "operaciones psicológicas", pero oficialmente dicho centro de instrucción fue nombrado Escuela de Relaciones Civiles y Militares.

Sin embargo, las diversas transformaciones que estaba atravesando el Ejército de Colombia desde mediados de la década de los noventa, y que se consolidaron en la reforma militar a inicios del siglo XXI, proporcionaron el surgimiento de un nuevo término: "acción integral", al cual esta institución se refiere como "[aquellas acciones que] incrementen el liderazgo y la moral de las tropas, consolide[n] nuestra legitimidad ante la población civil y disminuya[n] la voluntad de lucha de los terroristas" (Primera Línea, 2014). Por otra parte, Correa (2006) afirma que la acción integral se convirtió en un elemento clave que pasó a considerarse una parte fundamental de las operaciones militares en Colombia. Es más, en los documentos que estructuran la reorganización de la doctrina militar del Ejército, se reconoce la acción integral, junto a la transformación de las fuerzas especiales, la aviación del Ejército y la inteligencia militar, como uno de los elementos clave que permitieron la modernización del Ejército y la neutralización del plan estratégico de las FARC-EP a inicios del siglo XXI (Ejército de Colombia, 2016).

Así, las acciones propagandísticas del Ejército ya no estuvieron sometidas a las capacidades y la buena voluntad de los oficiales desplegados por el territorio nacional, sino que estas empezaron a ser coordinadas desde los más altos niveles de la institución. Es allí donde aparecen dos de las campañas más importantes de propaganda militar en Colombia en los últimos años, con una alta exposición en medios de comunicación masiva como televisión y radio. La primera, Los héroes en Colombia sí existen, fue dirigida por el Ejército de Colombia, creada por la agencia de publicidad McCann Erickson y los spots televisivos producidos por Direktor Films. La segunda campaña, La desmovilización es la salida, fue liderada por la Presidencia de la República 
y desarrollada por la agencia de publicidad Lowe-SSP3 (que posteriormente se convirtió en MullenLowe).

\section{Un mensaje persuasivo construido entre la retórica y la seducción}

Antes de entrar en detalle en el análisis de las dos campañas anteriormente mencionadas, es necesario destacar que una serie de académicos han intentado responder a la pregunta “ ¿cómo se construye el mensaje persuasivo?", y para ello han acudido, generalmente, al análisis de la retórica, basándose en el supuesto de que la persuasión publicitaria se construye a través de esta; enfoque que ha sido tomado por Capdevila (2004) y Toro (2008), por citar solo algunos ejemplos. En tal sentido, es común escuchar la expresión "retórica de la publicidad" - o "de la propaganda"-. Sin embargo, este enfoque ignora que la publicidad y la propaganda, fundamentalmente, despliegan un ejercicio de seducción sobre las audiencias a las que se dirigen.

Es decir, tanto la publicidad como la propaganda construyen su mensaje a través de la combinación de retórica e imágenes seductoras. Incluso, es posible ver que numerosos anuncios, hoy en día, no poseen textos y se configuran en torno a imágenes de este tipo. Este fenómeno, en el campo de la publicidad, ya había sido estudiado por Requena y Ortiz de Zárate en su texto El espot publicitario. La metamorfosis del deseo (1995b). De manera similar, Baudrillard ya sostenía que "[...] en la sociedad de consumo, el papel principal de la publicidad [es] [...] la exacerbación generalizada del deseo" (Arango \& Álvarez, 2011, p. 22). Y si bien la propuesta de estos autores solo se limita a anuncios con fines comerciales, es posible advertir que dicho fenómeno también se extiende a la propaganda política. Basta con revisar someramente una campaña electoral para advertir que los candidatos, básicamente, se encuentran en un ejercicio de seducción sobre sus posibles votantes.

En otras palabras, un candidato que aspira a un cargo de elección popular necesita despertar el deseo de quienes votarán por él. Sin embargo, es necesario destacar que dicho deseo se sublima a través de conceptos como "admiración", "confianza" o "respeto", que en el más extremo de los casos pueden llegar al fanatismo. Esto explica por qué, en la actualidad, miles de personas se convierten en seguidores de un personaje político. En sentido literal, lo desean, aunque dicho deseo es claramente sublimado. Pero el ejercicio de seducción sobre los votantes no acaba en el momento en que culminan las elecciones, pues quien se convierte en gobernante deberá mantener seducidos a los ciudadanos si quiere gozar de alta popularidad como un requisito indispensable de la gobernabilidad. Así, el término “campaña permanente" se ha vuelto cotidiano en la política contemporánea, 
tal como lo destaca Funk (2013) en su estudio sobre el caso de Sebastián Piñera como presidente de Chile, quien realizó durante su primer mandato importantes esfuerzos por elevar su popularidad, presentándose como un hombre cercano a su pueblo, o López y Angulo (2018), quienes exponen las acciones propagandísticas de Rafael Correa para mantenerse en el poder en Ecuador a través de un ejercicio de "espectacularización" de su poder.

De esta manera, si la propaganda política busca despertar una pulsión erótica sublimada de los gobernados hacia el candidato propio, también buscará encausar la pulsión destructora sobre los opositores, tal como la describe Freud (1976). Esta exaltación se realiza a través de una serie de técnicas que han sido descritas por Doob (1985), Tchakhotine (1985), Beaudoux, D’Adamo y Slavinsky (2011), y que Domenach (1968) categoriza en lo que él llamó “el fenómeno de la contrapropaganda", que en el mundo contemporáneo ha convenido en llamarse “campaña negativa”, como destacan García y D’Adamo (2013).

Así, la seducción es un ejercicio obligatorio para el poder, pues quienes aspiran al poder o ya gozan de él deben hacerse desear por sus seguidores. Las investigaciones que realizó Adorno (2004) en colaboración con LeoLowenthal, Massing y Horkheimer sobre la propaganda nazi y la desarrollada por los predicadores radicales norteamericanos llegaban a la conclusión de que el éxito de dicha propaganda se basaba en su uso de los mecanismos inconscientes de sus audiencias. El éxito de esta propaganda fascista no estaba en la coherencia del discurso en torno a una idea política concreta, sino en la explotación de los mecanismos inconscientes del público. Así, el espectáculo visual y la exacerbación de las pulsiones se convertían en un elemento fundamental de la propaganda política, pues todo poder necesita convertirse, así, en un espectáculo, pues "solo alcanza y luego pervive en dicho poder quien es capaz de hacerse desear” (González, 1995, p. 60).

Ahora, si bien este fenómeno puede parecer lejano a la propaganda militar, esta investigación halló considerable evidencia que demuestra la cercanía entre la exacerbación del deseo y la propaganda militar en Colombia.

\section{Héroes colmados de deseo}

Tal como se afirmó anteriormente, la campaña Los héroes en Colombia sí existen se inició en 2006 con el objetivo de mejorar la imagen institucional ante diversas audiencias, entre las que se destacaban los mismos integrantes del Ejército de Colombia y la opinión pública. La campaña se emitió en una serie de oleadas televisivas, acompañadas por otros medios como vallas, flyers, etc., de las cuales esta investigación se centró en once spots. Sin embargo, para exponer en este texto cómo el deseo se convierte en el 
tópico principal sobre el que la campaña propagandística se ha desarrollado, abordaremos cinco anuncios televisivos presentados en tres oleadas desde 2007 hasta 2009.

El primer anuncio se titula "Autógrafo" y fue emitido en 2007. La trama presenta a un niño que viaja en el auto de sus padres y en medio de un atasco vial se encuentra con un camión del Ejército que transporta soldados. A pesar de que llueve, el niño se baja del auto y le pide un autógrafo a uno de los soldados. El spot culmina con el soldado que firma su autógrafo y una voz en off que enuncia: "Los héroes en Colombia sí existen. Ejército Nacional", lo que le anuncia al televidente que los soldados del Ejército son héroes.

Si entendemos que un relato es "la narración del trayecto del deseo de un Sujeto, configurado por su Tarea y su Objeto" (González, 2006, p. 235), es posible afirmar que el anuncio se edifica en un pequeño relato de 30 segundos, donde el sujeto (personaje principal) es el niño que busca el autógrafo del soldado. El niño asume una posición activa en el relato y se moviliza gracias al deseo que siente por el soldado. En tal sentido, el soldado que viaja en el camión, más allá de ser un héroe, es un objeto de deseo para el niño. Claro, de lo que hablamos aquí es de un deseo sublimado, enmascarado en la admiración, pero no por ello deja de ser deseo. El suspense se construye a partir de los obstáculos que enfrenta el sujeto para acceder a su objeto de deseo; en este caso, en el caminar bajo la lluvia para obtener el autógrafo del soldado.

En consecuencia, si entendemos que la tarea es una donación que se le hace al sujeto por parte de un destinador o un mentor, en esencia un personaje diferente al sujeto, entenderemos que en este relato, propiamente, no hay una tarea de por medio. Es decir, no hay un deber que cumplir. El niño no actúa porque le hayan dado la tarea de conseguir el autógrafo, sino únicamente porque lo desea.

Ahora bien, entendemos el storytelling como la tendencia comunicativa en la cual, a través de historias, se promueven los valores de las organizaciones, más que los atributos de sus productos (Méndiz, Regadera \& Pasillas, 2018). Al interior de esta tendencia se advierte que el espectador es invitado a identificarse con uno de los personajes de la narración. En este sentido, el anterior spot nos invita, como televidentes que hacemos parte de lo que algunos autores han denominado "sociedad civil", a identificarnos con el niño y no con el soldado. Se nos incita a sentir la misma admiración, el mismo deseo que siente el niño hacia los soldados de la institución. Por el contrario, si el televidente es un militar activo, se identificará con el soldado del anuncio que le dice que él es objeto de deseo de los colombianos que lo admiran y que, por tanto, deberá responder con amabilidad a dicha admiración. 
Figura 1 Fotogramas del spot "Autógrafo"

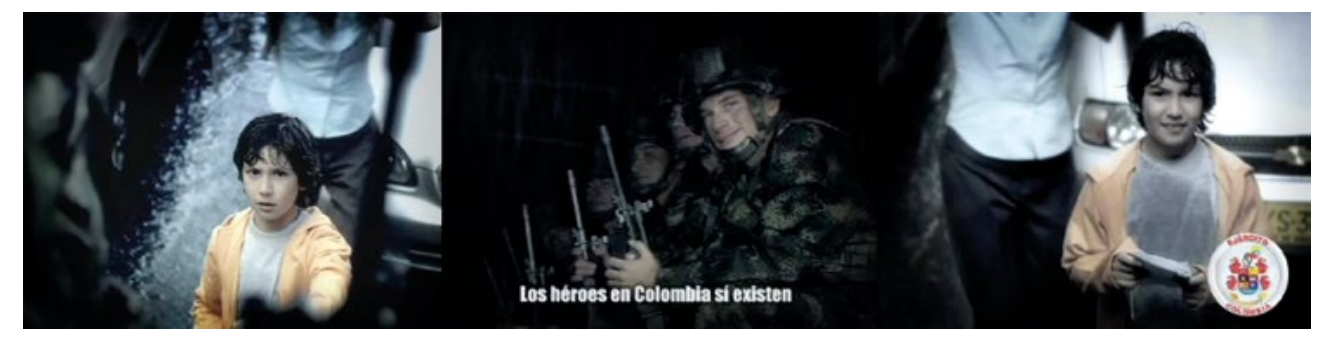

Fuente: Elaboración propia

Una oleada posterior de la campaña, emitida en 2009, está compuesta por tres spots televisivos que se titulan "Río", "Helicóptero" y "Noche". A diferencia de la oleada donde aparece "Autógrafo", estos anuncios no son, propiamente, relatos. Es decir, no nos presentan una narración, sino que son una coartada narrativa, una simulación de narración, pues nada se está narrando. Ello se debe a que son, básicamente, monólogos de soldados que le hablan a la cámara y, por tanto, al televidente.

El deseo está puesto en escena a través de las palabras y los gestos que los soldados le hacen al televidente. Por ejemplo, en el spot "Noche", el soldado dice lo siguiente: "Quiubo. Qué bueno hablar con usted en noches así. Es que sonrisas como la suya lo hacen sentir a uno muy bien. Me enteré de que le aprobaron el crédito para la tiendita. ¡lch!, casi que no. Pero eso va a ser un éxito en el barrio, va a ver. Y quiere que le diga algo: a pesar de que no lo conozco, estoy dispuesto a dar la vida por usted".

La afirmación del soldado ha sido contundente. Le ha dicho al televidente que está dispuesto a morir por él, así no lo conozca. Inicialmente, el televidente puede pensar que la afirmación obedece al deber, porque los soldados se sacrifican a sí mismos porque el deber así lo exige. Sin embargo, eso no es lo que presenta el spot, pues lo que se evidencia, claramente, es una escena de seducción. El soldado ha coqueteado con el televidente, le ha dicho que se alegra de verlo y, exactamente, de verlo sonreír. En otras palabras, el soldado no está dispuesto a morir por el televidente porque ese sea su deber, sino porque desea al televidente, así no lo conozca.

El spot "Río" es bastante similar al anterior, pues un soldado le habla a la cámara y, por tanto, al televidente, y allí hace la misma afirmación: estar dispuesto a morir por él. Pero esta afirmación no se hace porque sea su deber, pues en ninguna parte del spot se enuncia esto, sino que se hace por deseo, porque el soldado que habla a la cámara afirma previamente: "[...] yo lo llevo a usted aquí", mientras señala con su mano su pecho. Es decir, el 
soldado dice que lleva al televidente en su corazón y, por tanto, lo quiere. De manera similar, el anuncio "Helicóptero" también presenta a un teniente del Ejército que hace la misma afirmación después de mostrar cercanía con el televidente, tras afirmar que conoce a su familia y que agradece lo bien que lo trataban -en su calidad de soldado-.

Figura 2 Fotogramas de los spots "Río", "Helicóptero" y "Noche"

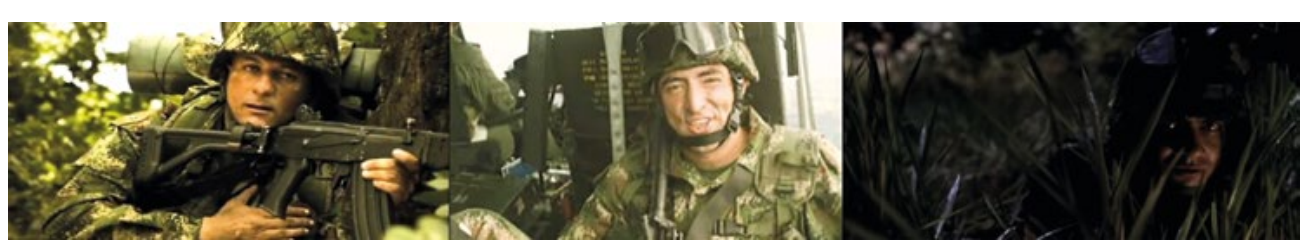

Fuente: Elaboración propia

Con relación a esta campaña, Gordillo (2013) sostiene que los spots amenazan al público porque se enuncia una vigilancia sobre el televidente. "Una vez anunciada la existencia del ojo vigilante del héroe [...], es inoculado de miedo para el control (se anuncia la vigilancia)" ( $p, 13)$. Sin embargo, nuestra investigación sostiene que los spots aquí mencionados no acuden a dicha lógica -aunque sí lo hace el spot titulado "Camuflaje", que a todas luces es amenazante y que aparecerá en una oleada posterior a "Autógrafo"-. Ello se debe a que, como sostenemos en este artículo, la lógica del deseo es la que se impone en la campaña, pues se invita al televidente a desear a los soldados a través de microrrelatos o coartadas narrativas.

Una posterior oleada también fue transmitida en 2009 y estuvo compuesta por dos anuncios, "Rescate" y "Amigos", de la cual haremos referencia al primero, pues la lógica del deseo se mantiene, aunque esta cambia ligeramente su forma de manifestarse. La trama del anuncio presenta un helicóptero del Ejército que está haciendo el rescate de una persona, quien inicialmente parece ser un soldado. Sin embargo, al final del anuncio se descubre que quien yace herido es un subversivo. La voz en off enuncia: "En este helicóptero se está evacuando una unidad del ejército. Un artillero, un oficial, un suboficial, dos enfermeros y también va... quien atentó contra ellos y el país. Solo un héroe protege la vida, sin importar la de quién. Los héroes en Colombia sí existen".

Si bien en los anuncios anteriores no podía apreciarse que los soldados actuaran por el deber, sino por el deseo, en el anuncio "Rescate" sí puede evidenciarse la existencia de una tarea y un destinador o mentor que la enuncia. La voz en off actúa como destinador, como la institución castrense, 
que dona una tarea a los soldados: proteger la vida sin importar la de quién. En tal sentido, el deseo no es lo que moviliza a estos soldados, sino el deber. Es más, es este deber el que frena la pulsión de muerte - hacia el individuo que atentó contra ellos-. Entonces, cabe la pregunta: ¿dónde se halla el deseo?, pues no se visualiza que este movilice al sujeto de este relato.

El deseo se configura en torno a las imágenes que se proyectan al televidente, pues este es sometido a un espectáculo visual que muestra y enfatiza el poderío del Ejército. Es decir, la fábula de este anuncio bien puede consolidarse en 30 o 40 segundos, pero el spot fue desarrollado en dos versiones de 60 y 90 segundos para impactar a la audiencia. El anunciante ha decidido pautar un spot de considerable duración, no porque la trama así lo exija, sino por el ejercicio de seducción al que se somete al espectador a través de secuencias de soldados y helicópteros en ralentí, pues estas se convierten en un goce de la mirada.

Recordemos que la seducción, aunque se ayuda de los cinco sentidos, es esencialmente visual, es espectacular. En tal sentido, en este anuncio ella no se ha constituido en torno a la retórica del spot, sino en la imagen que le sugiere a la opinión pública que los soldados pertenecen a una institución poderosa, con la mejor y más novedosa tecnología, y también les sugiere a los integrantes del estamento militar que confien en sí mismos y en la institución a la que pertenecen.

\section{Figura 3 Fotogramas del spot "Rescate"}

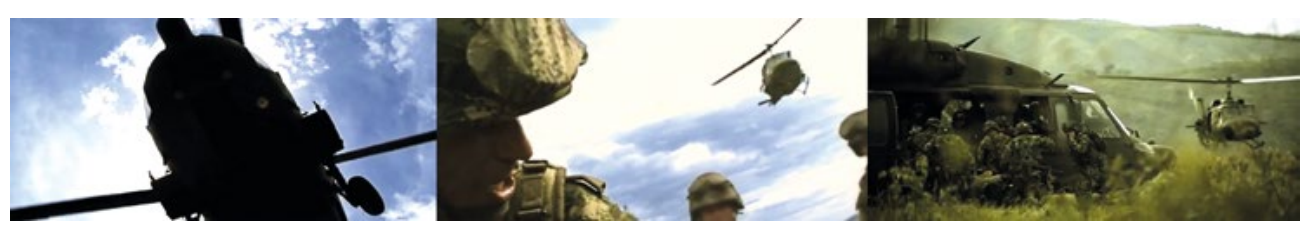

Fuente: Elaboración propia

\section{Desmovilicese y obtenga su objeto de deseo}

Si bien la campaña La desmovilización es la salida fue dirigida por la Presidencia de la República, una institución de carácter civil, esta claramente puede ser clasificada como una acción de propaganda militar o de guerra psicológica, según los postulados de Pizarroso (2005), pues su objetivo principal fue socavar la moral de los integrantes de grupos guerrilleros. Esto se realizó persuadiéndolos para que desertaran de sus organizaciones y se entregaran a las autoridades civiles y militares. 
Para tal fin, inicialmente, la Presidencia de la República contrató a los publicitarios de la agencia Lowe-SSP3, quienes descubrieron que los medios de comunicación idóneos para impactar a este público eran la radio y la televisión, especialmente en las transmisiones de partidos de fútbol, pues hallaron que los integrantes de los grupos guerrilleros veían estos eventos deportivos. Así, la campaña se lanzó el 12 de noviembre de 2007 mientras jugaba la Selección Colombia contra Suiza (Wentz, 2009).

La campaña inició con dos spots que titulamos "Fusilamiento" y "Aborto" y que están construidos a partir de microrrelatos que narran integrantes desmovilizados de estos grupos armados. Estos relatos también se apoyan en una voz institucional que asume la función de destinador que, mientas justifica la acción de los desmovilizados, dona una tarea al subversivo que ve el spot: desmovilizarse.

En "Fusilamiento", una voz en off de un subversivo enuncia: "Un día me ordenaron fusilar a una pareja a la que acusaron injustamente de traición. Era difícil, eran pelaos. Ella pidió morir primero para no ver muerto a su compañero. Esa mañana me di de cuenta [sic] que allá no éramos libres. Lo mejor era alejarnos de todo eso". Las imágenes que acompañan la voz son planos cerrados, bastante lúgubres, donde se presenta la ejecución de esta pareja.

En "Aborto", la voz en off de una guerrillera enuncia: "Yo quedé embarazada en la guerrilla y traté de ocultarlo, pero con tanto trabajo empecé a sangrar y me tocó contarle al comandante. Yo creí que él me iba a entender porque como su compañera también estaba embarazada. Eso que dicen los estatutos, que todos somos iguales... eso es pura mentira. A mí me hicieron abortar a mi bebé y el del comandante sí nació. Ahí empecé a pensar en irme, hasta que un día se me presentó la oportunidad". Ambos spots terminan con una voz en off que afirma: "Piénselo. Hay otra vida. La desmovilización es la salida".

A diferencia de la campaña Los héroes en Colombia sí existen, esta iniciativa no se dedica a exacerbar el deseo del televidente con el objetivo de mejorar la imagen institucional. Sin embargo, sí se configura en torno al deseo porque presenta a las organizaciones armadas como obstáculos para acceder al objeto de deseo. En el spot "Fusilamiento", el eros se enuncia de dos maneras: la primera, a través de la pareja asesinada, pues son dos jóvenes que ven truncado su romance -y su propia vida- por ser acusados "injustamente de traición". La segunda, a través de la afirmación del desmovilizado, quien dice: "esa mañana me di de cuenta [sic] que allá no éramos libres". Es decir, el subversivo no se siente libre para seguir su propio deseo y ello obedece a que los planificadores de la campaña descubrieron que los guerrilleros que protegían a los secuestrados se sentían tan confinados como sus víctimas (Wentz, 2009). 
El spot "Aborto" pone en juego el deseo de manera similar, pero sublimado a través del amor de una madre. Es decir, presenta a la organización guerrillera y más exactamente a sus cabecillas como los que le impiden tener a su propio hijo. La pulsión destructora es canalizada hacia los jefes de la organización, pues son presentados como injustos y asesinos que le impiden al público (los subversivos) alcanzar sus objetos de deseo, situación que la campaña siguió explotando a través de diversas acciones y medios de comunicación.

\section{Figura 4 Fotogramas de los spots "Fusilamiento" y "Aborto"}
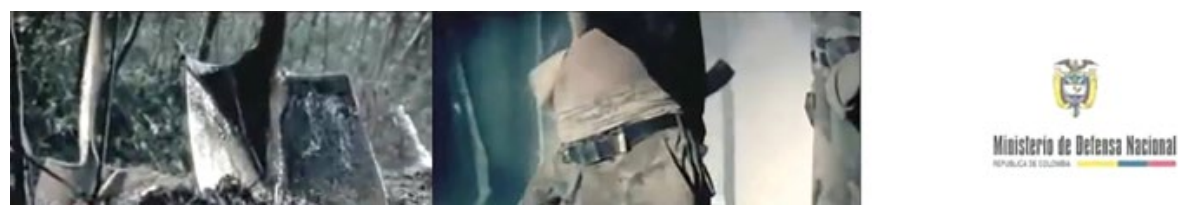

Fuente: Elaboración propia

\section{Conclusiones}

Al contrario de lo que podría pensarse, las campañas más significativas de propaganda militar en Colombia no acuden a tópicos morales que buscan persuadir a las audiencias en torno a una manera correcta de actuar. Por el contrario, estas campañas acuden a la exacerbación de las pulsiones, tal como lo han hecho las campañas propagandísticas analizadas por Adorno y Horkheimer.

Los spots aquí analizados de la campaña Los héroes en Colombia sí existen acuden a dos caminos para seducir a la audiencia. El primero, a través de breves relatos donde los soldados y la institución castrense son presentados como objetos de deseo que son admirados por la población gracias a su amabilidad o a su poderío. El segundo camino consiste en presentar coartadas narrativas en forma de testimoniales que se convierten en un juego de seducción entre el soldado que habla a la cámara y el televidente que mira la pantalla. En este diálogo, o más exactamente en el monólogo, el soldado no habla de las cualidades de la institución militar, como podría esperarse, sino que expresa su deseo hacia el televidente diciéndole que lo quiere, que se alegra de verlo y que se siente bien y agradecido por ser cercano a él.

La enunciación fílmica, semejante al cine hollywoodense, abundante en imágenes en ralentí que presentan helicópteros y armas, se convierte en un 
disfrute para el televidente, es en sí misma un espectáculo para que este la consuma. Alí también se consolida la seducción hacia el espectador, pues se presenta la institución militar y a sus miembros como poderosos, dignos de ser admirados y deseados.

De manera similar, la campaña La desmovilización es la salida no acude a argumentos que podríamos considerar morales, como indicar la aparente injusticia de la causa revolucionaria, su posible anacronismo o el cuestionado actuar de los miembros de la organización subversiva; tampoco acude a concepciones maniqueas del mundo. Todo lo contrario, la campaña se sustenta, claramente, en el deseo de su audiencia, presentándolo como algo inalcanzable para quienes continúen en la organización rebelde. Establecer una relación de pareja duradera, gozar de un trato justo o tener un hijo se presentan como imposibles hasta que el subversivo abandone las filas guerrilleras.

Lejos de lo que pudiera esperarse, el Estado y las Fuerzas Militares no son presentadas como los antagonistas de los subversivos, sino que esta función es asumida por los líderes de la organización guerrillera, quienes son presentados como opresores del guerrillero raso y que le impiden acceder a su objeto de deseo. En este sentido, se promueve, de manera velada, la pulsión destructora hacia dichos líderes y no hacia los miembros de las fuerzas gubernamentales.

\section{Referencias}

Adorno, T. (2004). Escritos sociológicos I. Obra Completa 8. Madrid: Akal.

Arango, C. \& Álvarez, M. (2011). Nuevas recepciones, viejos consumos. Las recientes ofertas de contenido como agentes de transformación de lo imaginario. Anagramas, 9(19), pp. 17-34.

Beaudoux, V.; D’Adamo, O. \& Slavinsky, G. (2011). Propaganda gubernamental. Tácticas e iconografias del poder. Buenos Aires: La Crujía Ediciones.

Boyd, C. (2007). Army IO is PSYOP. Influencing more with less. Military Review, 85(3), pp. 67-75. Capdevila, A. (2004). El discurso persuasivo: La estructura retórica de los spots electorales en televisión. Barcelona: Universidad Autónoma de Barcelona.

Correa, M. (2006). Desinformación y propaganda: estrategias de comunicación del conflicto armado colombiano. Reflexión política, 8(15), pp. 94-106.

Domenach, J. (1968). La propaganda política. Buenos Aires: Editorial Universitaria de Buenos Aires.

Doob, L. (1985). Goebbels y sus principios propagandísticos. En: M. Moragas (ed.), Sociología de la comunicación de masas III. Propaganda política y opinión pública (pp. 122-153). Barcelona: Editorial Gustavo Gili.

Ejército de Colombia (2016). Manuales fundamentales del Ejército. Doctrina Damasco. Bogotá: Centro de Doctrina del Ejército. 
Faucher, C. (2019). Transnational cultural propaganda. French cultural policies in Britain during the Second World War. French politics, Culture e Society, 37(1), pp. 48-69.

Fernández, A. (2006). Las relaciones públicas como elemento tangencial entre la publicidad, propaganda, información y otras áreas de la comunicación. Revista Mexicana de Ciencias Políticas y Sociales, 48(196), pp. 159-170.

Freud, S. (1976). Esquema del psicoanálisis. Buenos Aires: Paidós.

Funk, R. (2013). Chile en 2012: La campaña permanente. Revista de Ciencia Política, 33(1), pp. 83-99.

García, V. \& D’Adamo, O. (1995a). El discurso televisivo: espectáculo de la posmodernidad. Madrid: Ediciones Cátedra.

González, J. (1995). El discurso televisivo: espectáculo de la posmodernidad. Madrid: Ediciones Cátedra.

_-- (1995b). El espot publicitario. La metamorfosis del deseo. Madrid: Ediciones Cátedra.

_-- (1996). El texto: tres registros y una dimensión. Trama y fondo, (1), pp. 1-32.

_-- (2006). Clásico, manierista y postclásico. Los modos del relato en el cine de Hollywood. Madrid: Castilla Ediciones.

--- (2013). Propuesta de una matriz de codificación para el análisis de las campañas negativas. OPERA - Observatorio de Políticas, Ejecución y Resultados de la Administración Pública, (13), pp. 7-23.

Gordillo, C. (2013). Inmunitas-Biopolítica: miedo, poder soberano y libertad. Una aproximación crítica a la propaganda militar en Colombia. Mediaciones, 9(11), pp. 8-19. Huici, A. (2004). Los heraldos de acero. La propaganda de guerra y sus medios. Sevilla: Comunicación social ediciones y publicaciones.

López, M. \& Angulo, N. (2018). Analysis of the perceptual elements in the communications media and the strategies of propagandistic communication of Rafael Correa, president of Ecuador between 2007 and 2017. Revista Kepes, (17), pp. 151-181.

Méndiz, A.; Regadera, E. \& Pasillas, G. (2018). Valores y storytelling en los fashion films. El caso de Tender Stories (2014-2017), by Tous. Revista de Comunicación, 17(2), pp. 316-335.

Palencia-Lefler, M. (2008). 90 Técnicas de relaciones públicas. Manual de Comunicación Corporativa. Barcelona: Bresca Profit.

Pizarroso, A. (2009). Diplomáticos, propagandistas y espías. Estados Unidos y España en la Segunda Guerra Mundial: Información y propaganda. Madrid: Consejo Superior de Investigaciones Científicas.

_-_- (2005). Nuevas guerras, vieja propaganda (de Vietnam a Irak). Madrid: Cátedra.

Primera Línea (2014). Edición especial. Principios y valores, 15, pp. 24-25.

Tchakhotine, S. (1985). El secreto del éxito de Hitler: la violencia Psíquica. En: M. Moragas (ed.), Sociología de la comunicación de masas III. Propaganda política y opinión pública (pp. 154-191). Barcelona: Editorial Gustavo Gili.

Thomson, O. (1999). Easily lead. A history of propaganda. Gloucestershire: Sutton Publishing.

Toro, L. (2008). Semiosis publicitaria: Una aproximación desde el análisis del discurso. Medellín: Sello Editorial Universidad de Medellín.

Vargas, A. \& Patiño, C. (2006). La reforma militar en Colombia. Contexto internacional y resultados esperados. Medellín: Editorial Universidad Pontificia Bolivariana. 


\section{7}

Comunicación

número 42

Enero-junio

2020

Went, L. $(2009,11,16)$. Call it guerrilla marketing: Colombia uses ads to persuade rebels to turn themselves. Advertising age, 80(39). Disponible en: https://adage.com/article/ global-news/colombia-ads-persuade-rebels-turn/140548.

Young, K. (1967). La opinión pública y la propaganda. Buenos Aires: Paidós. 